\title{
The effect of fatigue on plantar pressure distribution during running in view of running injuries
}

Tine M Willems*, Roel De Ridder, Philip Roosen

From 3rd Congress of the International Foot and Ankle Biomechanics Community

Sydney, Australia. 11-13 April 2012

\section{Background}

Several risk factors for the development of running injuries have been identified, however, the etiology is still not completely clear [1]. A number of prospective studies have identified gait-related risk factors for lower leg overuse injuries [2-6]. On the other hand, running injuries only develop by overloading the lower extremity. Fatigue can therefore be hypothesized to be a primary contributing factor. However, in determining injury etiology the relationship between the injury, the gait-related risk factors and overloading by fatigue is a complex model and the amount of contribution of each factor is difficult to assess. It might therefore be interesting to check 1) the interaction between fatigue and the roll-off pattern during running and 2)if fatigue generates specific gait-related risk factors for running injuries.

\section{Materials and methods}

Prior to and after a $20 \mathrm{~km}$ run, force distribution underneath the feet of 52 participants was registered using Footscan ${ }^{\circledR}$ pressure plates while the participants ran shod at a constant self-selected pace. Peak force, mean force
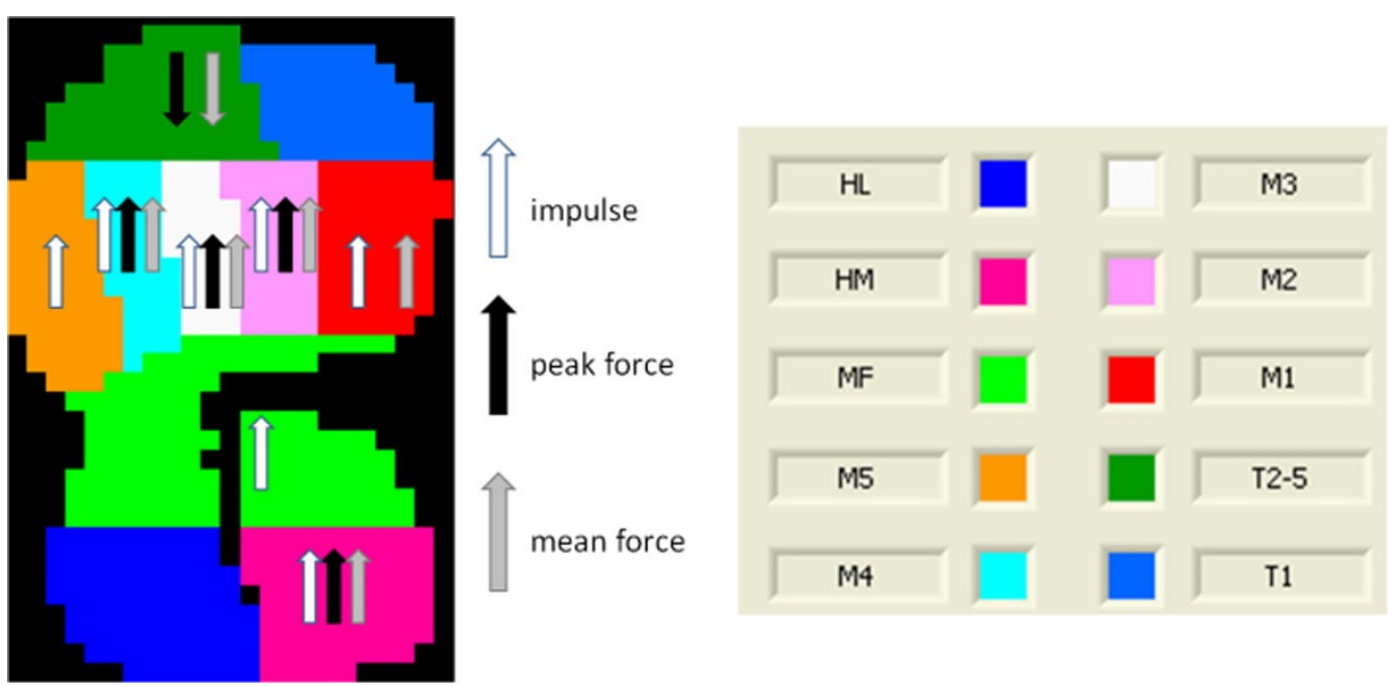

Figure 1 Significantly changed impulse, peak force and mean force for the different zones

*Correspondence: tine.willems@ugent.be

Department of Rehabilitation Sciences and Physiotherapy, Ghent University,

Ghent, Belgium, 9000

(c) 2012 Willems et al; licensee BioMed Central Ltd. This is an Open Access article distributed under the terms of the Creative Commons 
and impulse were registered underneath different zones of the foot. In addition, temporal data were derived and a medio-lateral force ratio was calculated during the roll-off.

\section{Results}

After the run, increases in the loading of the forefoot, midfoot and medial heel were noted and decreases in loading of the lateral toes. Significant differences are presented in Figure 1. In the forefoot push off phase a more lateral pressure distribution was observed.

\section{Conclusions}

Several of the significantly increased variables have been identified as risk factors for running injuries as stress fractures, patella-femoral pain syndrome and exerciserelated lower leg pain. The results of this study demonstrated plantar pressure alterations after long-distance running which could give additional information related to several running injuries.

Published: 10 April 2012

\section{References}

1. Van Gent RN, Siem D, van Middelkoop M, et al: Incidence and determinants of lower extremity running injuries in long distance runners: a systematic review. Br J Sports Med 2007, 41:469-80.

2. Ghani Zadeh Hesar N, Van Ginckel A, Cools A, et al: A prospective study on gait-related intrinsic risk factors for lower leg overuse injuries. $\mathrm{Br} J$ Sports Med 2009, 43:1057-1061.

3. Thijs $Y$, De Clercq D, Roosen $P$, et al: Gait-related intrinsic risk factors for patellofemoral pain in novice recreational runners. Br J Sports Med 2008, 42:466-471.

4. Thijs $Y$, Van Tiggelen $D$, Roosen $P$, et al: A prospective study on gaitrelated intrinsic risk factors for patellofemoral pain. Clin J Sport Med 2007, 17:437-445.

5. Van Ginckel A, Thijs Y, Hesar NG, et al: Intrinsic gait-related risk factors for Achilles tendinopathy in novice runners: a prospective study. Gait Posture 2009, 29:387-391.

6. Willems TM, De Clercq D, Delbaere $K$, et al: A prospective study of gait related risk factors for exercise-related lower leg pain. Gait Posture 2006, 23:91-98.

doi:10.1186/1757-1146-5-S1-P33

Cite this article as: Willems et al:: The effect of fatigue on plantar pressure distribution during running in view of running injuries. Journal of Foot and Ankle Research 2012 5(Suppl 1):P33.

\section{Submit your next manuscript to BioMed Central} and take full advantage of:

- Convenient online submission

- Thorough peer review

- No space constraints or color figure charges

- Immediate publication on acceptance

- Inclusion in PubMed, CAS, Scopus and Google Scholar

- Research which is freely available for redistribution

Submit your manuscript at www.biomedcentral.com/submit 